\title{
急性肺血栓塞栓症を合併した慢性血栓塞栓性肺高血圧症に対して 二期的手術を施行した 1 例
}

\author{
新美 - 帆*田中恒有* 朝 野直城* 太田和文* \\ 齊藤 政 仁* 権重 好* 石田敬 - **高野弘志*
}

\begin{abstract}
症例は 46 歳男性. 肺炎の診断にて他院で入院加療を受けていた。経過中に呼吸苦が増悪し，造影 CT で肺 動脈内に血栓像を認め，急性肺血栓塞栓症の診断で当院に救急搬送された．経胸壁心エコーで右房内に大き な浮遊血栓を認めたため同日緊急手術を施行し，右房と肺動脈内の新鮮血栓を除去したが，肺動脈内には広 範に器質化血栓も認め，基礎に慢性血栓塞栓性肺高血圧症が存在していたことが判明した．肺動脈血栓内膜 摘除術（Pulmonary endarterectomy : PEA）の器具の準備がなく，人工心肺から離脱困難であったため, 経皮的心肺補助装置（Percutaneous cardiopulmonary support：PCPS）を装着していったん手術を終了し た。術後も PCPS から離脱困難であったため, 術後 5 日目にPEA を施行し，人工心肺から離脱可能となっ た. 術後右心カテーテル検查では肺高血圧症を認めず，第 22 病日に独歩退院となった．日心外会誌 47 巻 3 号 : 100-104 (2018)
\end{abstract}

キーワード：慢性血栓塞栓性肺高血圧症；急性肺血栓塞栓症；肺動脈血栓内膜摘除術

Acute Pulmonary Thromboembolism Associated with Chronic Thromboembolic Pulmonary Hypertension Treated by Emergency Embolectomy and Delayed Pulmonary Endarterectomy Kazuho Niimi*, Koyu Tanaka*, Naoki Asano*, Kazunori Ota*, Masahito Saito*, Shigeyoshi Gon*, Keiichi Ishida** and Hiroshi Takano* (Department of Cardiovascular Surgery, Dokkyo Medical University Saitama Medical Center*, Koshigaya, Japan, and Department of Cardiovascular Surgery, Chiba University Graduate School of Medicine**, Chiba, Japan)

A 46-year-old man who had been hospitalized for treatment of pneumonia was referred to our hospital with a diagnosis of acute pulmonary thromboembolism. Multi-detector row computed tomography revealed massive thrombi in the bilateral main pulmonary arteries. Transthoracic echocardiography showed dilated right heart chambers and a large floating thrombus in the right atrium. Emergency thromboembolectomy was performed. Although fresh thrombi were removed from the right atrium and left main pulmonary artery, organized old thrombi were present in the bilateral pulmonary arteries, leading to a diagnosis of chronic thromboembolic pulmonary hypertension. Because no instruments were available for pulmonary endarterectomy, the surgery was terminated with percutaneous cardiopulmonary support. Five days postoperatively, pulmonary endarterectomy was performed under deep hypothermic circulatory arrest. The postoperative course was uneventful, and the patient returned to his preoperative lifestyle without the need for oxygen support. Jpn. J. Cardiovasc. Surg. 47 : 100-104 (2018)

Keywords : chronic thromboembolic pulmonary hypertension; acute pulmonary thromboembolism ; pulmonary endarterectomy

慢性血栓塞栓性肺高血圧症（Chronic thromboembolic pulmonary hypertension : CTEPH) は器質化した血栓によ り肺動脈が慢性的に閉塞し肺高血圧症を来す疾患である が, 急性肺血栓塞栓症 (Acute pulmonary thromboembo- lism : APTE）が新たに合併した場合，初発の APTE と鑑 別が難しく，治療に難渋することがある．今回，右房内の 浮遊血栓を伴うAPTE の診断で緊急血栓摘除術を行った が，術中所見で CTEPH の存在が判明し，後日二期的に肺
2017 年 10 月 5 日受付， 2017 年 12 月 19 日採用

Corresponding author: Hiroshi Takano

Department of Cardiovascular Surgery, Dokkyo Medical

University Saitama Medical Center, Koshigaya, Japan

Email : htakano@dokkyomed.ac.jp

* 獨協医科大学埼玉医療センター心臟血管外科

₹ 343-8555 越谷市南越谷 2-1-50

**千葉大学大学院医学研究院心臓血管外科
本研究に打いて一切の利益相反や研究資金の提供はない.

None of the authors of this manuscript has any financial or personal relationship with other people or organizations that could inappropriately influence their work. 
動脈血栓内膜摘除術 (Pulmonary endarterectomy: PEA) を施行して救命できた 1 例を経験したので報告する.

\section{症例}

症例 : 46 歳, 男性.

主訴：呼吸苦.

既往歴：アトピー性皮膚炎，小児喘息.

喫煙歴：28 年, 20 30 本/日

現病歴： 2015 年 2 月に呼吸苦のため前医を受診し, 肺 気腫と診断され，以降外来通院していた。同年 7 月に左下 腿浮腫を認めたが，3 日程度で消失したため医療機関を受 診しなかった。9月下旬に $20 \sim 30 \mathrm{~m}$ の歩行で呼吸困難を 自覚するようになり，9月 26 日肺炎の診断で前医に入院 し抗生剤治療を受けていたが，呼吸苦が増悪したため 10 月 2 日造影 $\mathrm{CT}$ を撮影したところ肺動脈内に血栓像を認 め, 急性肺血栓塞栓症の診断で当院救命救急センターへ転 院搬送された。

入院時現症: 身長 $178 \mathrm{~cm}$, 体重 $70 \mathrm{~kg}$, 体温 $36.0^{\circ} \mathrm{C}$, 脈拍 97 回/分- 整, 血圧 $131 / 95 \mathrm{mmHg}$, 呼吸数 19 回, 呼吸音清・左右差なし. 左大腿部に腫脹, 圧痛あり.

血液検查所見 : AST $125 \mathrm{U} / \mathrm{L}$, ALT $170 \mathrm{U} / \mathrm{L}$, ALP 486 U/L, WBC 9,400/ $\mu \mathrm{l}$, CRP $0.9 \mathrm{mg} / \mathrm{dl}$, D-dimer $18.86 \mu \mathrm{g} /$ $\mathrm{ml}$.

動脈血ガス所見 : 室内空気にて $\mathrm{PaO}_{2}$ 84.1 Torr, $\mathrm{PaCO}_{2}$ 27.4 Torr (room air).

胸部 X 線所見 (Fig. 1, left panel）：心胸比は $58 \%$ と心 拡大を認めた。両側肺野の透過性立進は明瞭ではなかっ た。

心電図所見 (Fig. 1, right panel)：心拍数 97 回/分，洞 調律. II, III, aVF，V1-4 で陰性 T波を認めた。
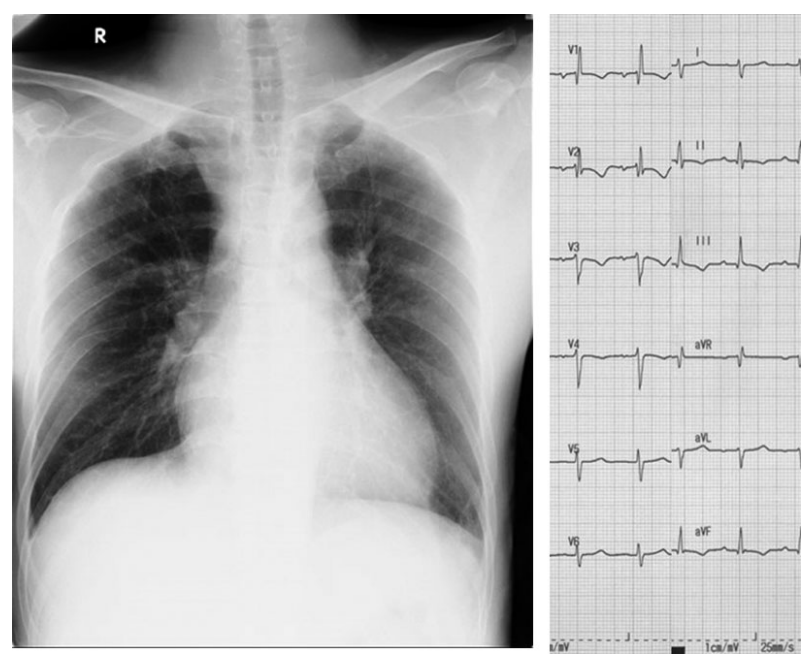

Fig. 1

Preoperative chest X-ray (left panel) and electrocardiogram (right panel).
経胸壁心臟超音波所見（Fig. 2）：左室拡張期径/左室収 縮期径 38/26 mm, 左室駆出率 57\% であり左室収縮能は比 較的保たれていたが，右室の圧排による左室の扁平化を認 めた。 三尖弁収縮期圧較差 $65 \mathrm{mmHg}$ と肺高血圧の所見を 認めた，中等度三尖弁閉鎖不全症を認め，また右房-右室 間を行き来する棍棒状浮遊物を認め血栓と考えられた。

全身造影 CT 所見（Fig. 3）：右房ならびに左右主肺動脈 に血栓と思われる像を認めた。また左浅大腿静脈にも血栓 と思われる像を認めた。

以上の経過と検査結果から右房内浮遊血栓を伴う APTE, 肺高血圧症, 左下肢深部静脈血栓症と診断した. 低酸素血症は認めないものの, 高度の右室圧負荷と右房内 に大きな浮遊血栓を認めたため, この浮遊血栓による新た な肺塞栓は致死的になると考え, 緊急手術の適応と判断 し，ただちに外科的血栓除去術を施行することとした。

手術所見 (1) : 血行動態破綻時に経皮的心肺補助法 (PCPS) が挿入できるよう右大腿動静脈にシースを挿入し たのちに麻酔導入を行った。導入後血圧は $60 \mathrm{mmHg}$ 台ま で低下し, 中心静脈圧は 30〜 $35 \mathrm{mmHg}$ まで上昇した。た だちに正中切開を行い上行大動脈送血, 上下大静脈脱血で 体外循環を開始した。右房を切開し内腔を観察したとこ ろ, 右房内に太さ $8 \mathrm{~mm}$ 長さ $15 \mathrm{~cm}$ の新鮮血栓塊を認め これを除去した (Fig. 4A). 大動脈遮断後, 肺動脈主幹部 より左主肺動脈を切開した. 左主肺動脈内にも新鮮血栓を 認めこれを可及的に除去した（Fig. 4B）が，さらに肺動 脈内には器質化した血栓を認めた。つづいて右肺動脈を切 開し観察すると, 新鮮血栓は認めず器質化した血栓を認め た。これにより基礎に CTEPH が存在していたことが判明 した. Jamieson の吸引剝離子など PEA に必要な手術器具

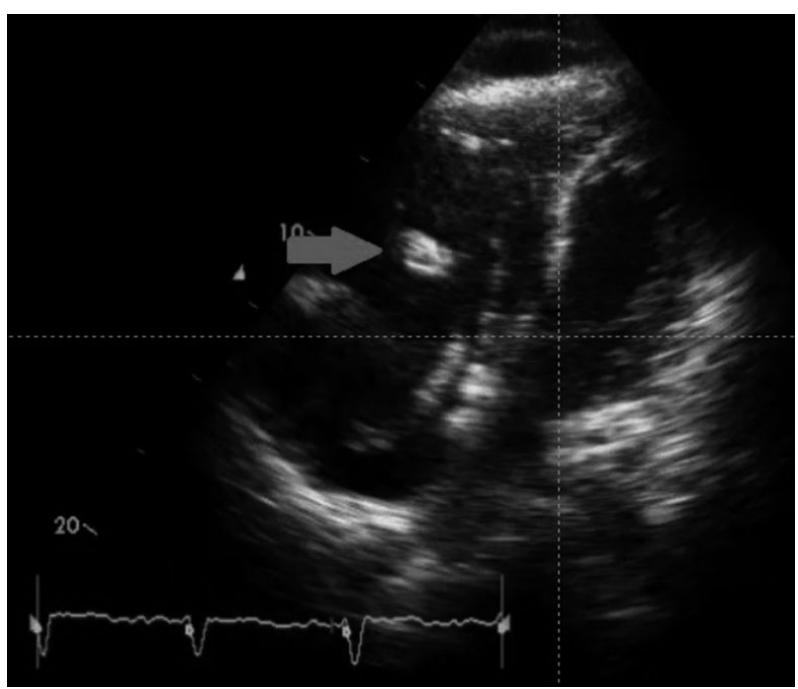

Fig. 2

Preoperative transthoracic echocardiogram showing a thrombus in the right ventricle (arrow). 


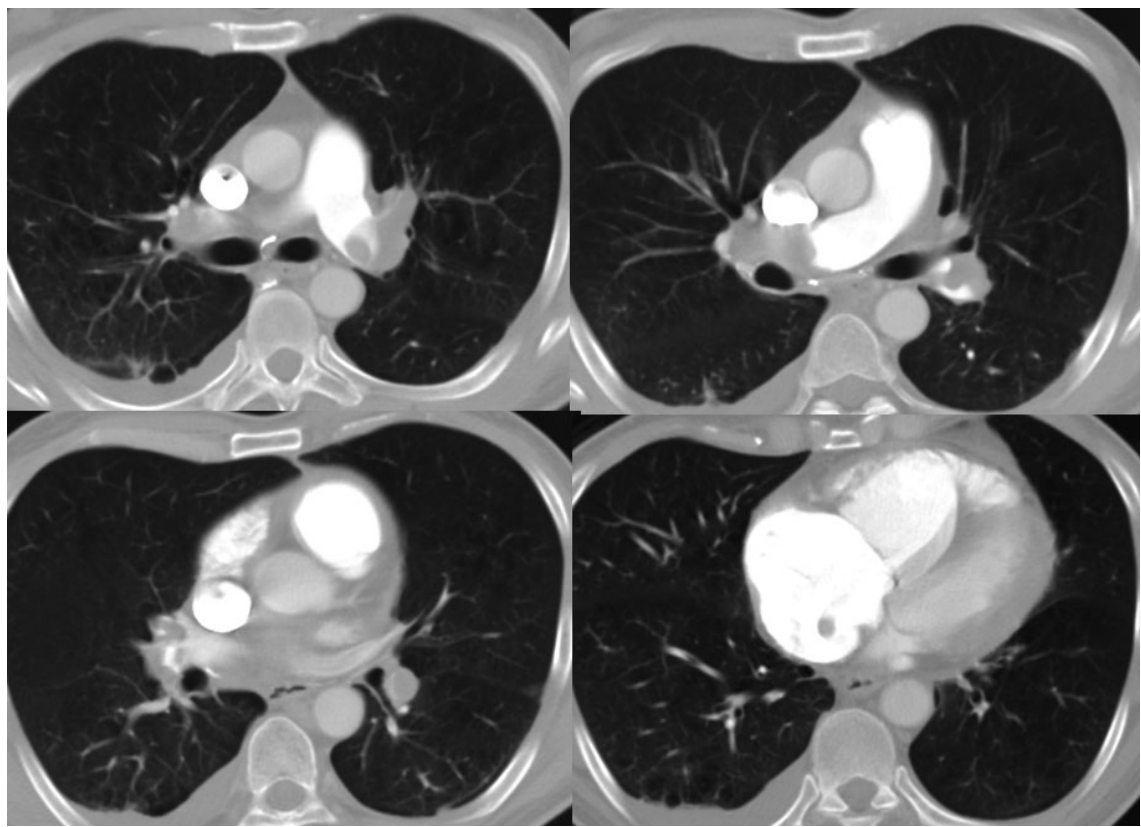

Fig. 3

Preoperative computed tomography showing thrombi in the bilateral main pulmonary arteries and the right atrium.

( A )

( B )

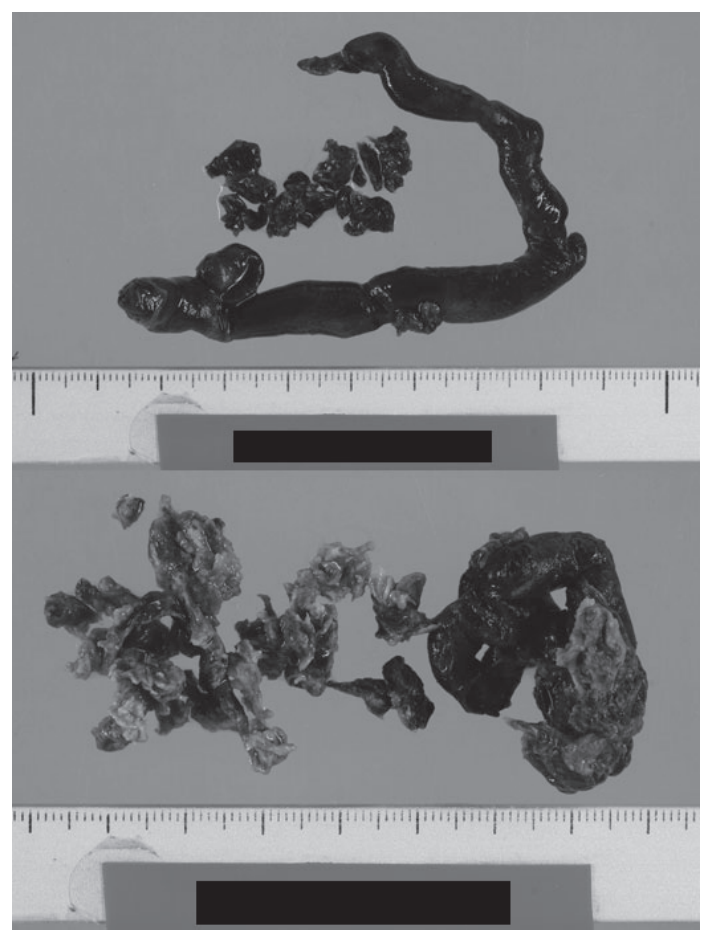

Fig. 4

Fresh and old thrombi removed during the first operation. (A) Fresh thrombi resected from the right atrium. (B) Fresh and old thrombi resected from the left pulmonary artery.

がなかったため両肺動脈を閉鎖し，カテコラミン補助下に 体外循環離脱を数回試みたが離脱は難しく, PCPS を挿入 し手術をいったん終了した。手術時間は 288 分，体外循環
時間は 161 分，大動脈遮断時間（心停止時間） 78 分で あった。

術後経過：利尿剂投与により全身浮腫の軽減に努め, 術 後第 2 日よりカテコラミンおよび肺血管拡張剤の投与下に PCPS からの離脱を連日試みたが，体血圧が保てず PCPS の離脱は困難であった。このため CTEPH に対する手術加 療が必要であると判断した. PEAに必要な器具を準備し たうえで初回手術の 5 日後に 2 回目の手術を行った。

手術所見(2)：体外循環開始後, 冷却中に右主肺動脈を切 開, Jamieson 吸引剝離子を用いて右上葉枝の器質化血栓 を内膜とともに剝離し摘出した. 大動脈遮断後膀胱温 $20^{\circ} \mathrm{C}$ で間歇的に循環停止とし, 右肺動脈中葉枝から下葉枝 の器質化血栓打よび内膜を剥離摘出した。つづいて主幹肺 動脈から左主肺動脈を切開し，左上葉枝，下葉枝の内膜を 亜区域枝まで摘除した (Fig. 5). 体外循環からの離脱は容 易であり, 平均肺動脈圧は約 $30 \mathrm{mmHg}$, 肺対体血圧比 $(\mathrm{Pp} / \mathrm{Ps})$ は 0.3 であった。手術時間 612 分, 体外循環時間 425 分, 大動脈遮断時間 (心停止時間) 88 分, 総循環停止 時間 55 分であった。

術後経過: 術後 2 日目（初回手術 7 日後）に気管チュー ブを抜管した。造影 CTでは右房内および肺動脈内に明ら かな血栓像はなく, 右心カテーテル検査で平均肺動脈圧 $15 \mathrm{mmHg}$, 肺血管抵抗は $131 \mathrm{dyn} / \mathrm{cm}^{5}$, 肺動脈楔人圧は 9 $\mathrm{mmHg}$ であった. 術後第 22 病日に独歩退院し, 術後 8 力 月目の現在再発なく外来フォロー中である. 


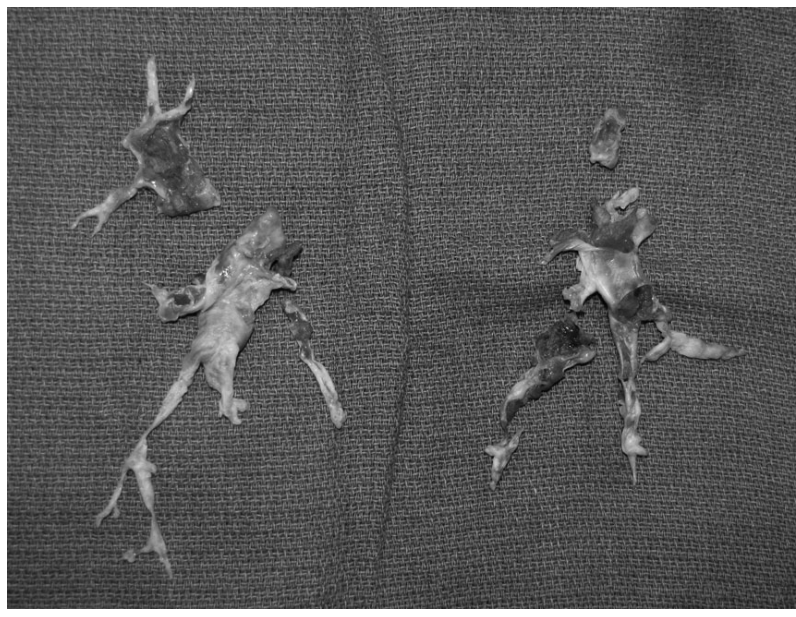

Fig. 5

Specimen removed from both lungs during pulmonary endarterectomy.

\section{考察}

APTE の治療は一般的には内科的に血栓溶解療法が行わ れることが多いが，ショック状態や血行動態が不安定な例 では外科的血栓摘除術の適応となる．また非ショック例で あっても，急速に心不全や呼吸不全が進行する例や，血栓 溶解療法が禁忌の例，あるいは右房から右室にかけて浮遊 血栓が存在する例では，外科的血栓摘除術の適応とされ る ${ }^{1)}$ 。一方 CTEPH は内科治療に限界があり, PEA が根治 的治療である2,3)。しかしながら, APTE と CTEPH は独立 して存在するわけではなく，急性期治療の後にも十分な臨 床症状の改善を得られない, いわゆる acute on chronic の 病態を示すものも多く経験される ${ }^{4)}$.

本症例では術中所見より初回手術前にAPTE が生じた ことは確かで, 右房から右室にかけて存在した大きな浮遊 血栓が飛散した場合には突然死につながるため，手術適応 とすることには問題なかったと考えられたが，基礎に CTEPH が存在することは診断できていなかった. APE と $\mathrm{CTEPH}$ では術式がまったく異なるため，新規の APE な のか， CTEPH に APTE が合併したものなのかを鑑別する ことは重要である ${ }^{5)}$.

CTEPH の画像診断的特徵として, マルチスライス CT (Multidetector computed tomography:MDCT) において 肺動脈の石灰化血栓, web, band, 狭窄後拡張が認められ ること，気管支動脈が拡張（>1.5 mm）していること， 主幹肺動脈が上行大動脈より太いことなどが報告されてい

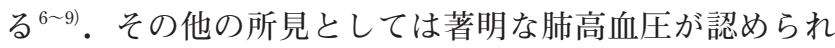
ること ${ }^{10)}$ ，心エコーでの右室肥大所見が認められること ${ }^{11}$ などが CTEPH を示唆する所見とされている．しかし実際 には鑑別困難なことも多く，本症例に打いても術後に
MDCT および心エコー所見を詳細に見直したが，これら の所見は明かではなく，今回の画像診断のみから APTE に CTEPH が合併しているか否かを鑑別することは困難で あったと思われた，櫻川ら ${ }^{4}$ は APTEに対する血栓溶解療 法後に肺血管内視鏡を行い, 慢性肺血栓塞栓症の存在を診 断できた 2 例を報告している。 また鯉江ら ${ }^{12}$ は, APTE と 慢性反復性肺血栓塞栓症の鑑別に，血管内超音波検查と血 管内視鏡検査の有用性を報告しており，これらの検査が， APTE と慢性肺血栓塞栓症の鑑別に有用となる可能性があ ると考えられた，本症例でも，かりに右房内浮遊血栓がな ければ, まず抗凝固療法や血栓溶解療法を行い, その反応 を観察し，さらに諸検査を行うことによって， CTEPHの 存在の有無を診断することが可能であったかもしれないと 考えられた.

しかしながら，本症例では半年以上前から呼吸苦の症状 があり, 症状の経過が長いという CTEPH の特徵をそなえ ていた。したがって，時間的余裕がなく緊急手術を行わね ばならない場合にも CTEPH の存在を念頭に打いて臨むべ きであったと反省させられた。

CTEPH に対する PEA は有効な治療法として確立され, 手術死亡率も改善傾向を認めているが ${ }^{1)}$, 本邦では年間 60 例くらいの手術が行われているのみで ${ }^{13,14)}$, 施行している 施設も限られている。手術にはJamieson 吸引剝離子など 特殊な手術器具が必要で, 超低体温循環停止下に器質化血 栓打よび内膜を区域枝・亜区域枝まで摘出しなければなら ない，また遺残肺高血圧症，気道出血，再灌流性肺水腫な ご，この手術に特有の合併症があり，予防策や治療法にも 熟知する必要がある ${ }^{15)}$ 。このため日本循環器学会の肺高血 圧症ガイドライン ${ }^{16)}$ では， CTEPH の診断打よび手術適応 の決定においては経験のある施設や外科医にコンサルトす ることが推奨されている．しかし本症例のように緊急的に 手術を施行しなければならない場合もあるため, 手術器具 の準備や, 術式および術後管理などの熟知など, 準備をし ておくことが重要と考えられた。

われわれが検索した限り，本症例のようにAPTE を合 併した CTEPH に対して二期的にPEA を行った報告は確 認できなかったが，PEAを施行している施設では，ただ ちに術式を変更し緊急の PEAが行われていると考えられ る。また経験のない施設では, PEA が行われないまま死 亡している症例も存在するのではないかと思われる．本症 例では手術器具の準備に時間を要したため, 二期的手術ま でに 5 日間の PCPS 補助を行ったが，可能であればより早 期にPEAを施行したほうがよかったものと考えられた。

\section{結語}

右房内の浮遊血栓を伴う APTE と診断し，緊急血栓摘 
除術を行ったが，術中所見で CTEPH の存在が判明し，二 期的にPEAを施行して救命できた 1 例を経験した。APTE の診断で血栓摘除術を施行する場合にも，CTEPH の可能 性を考慮し，PEAが施行できるよう準備しておくことが 重要であると考えられた。

\section{文献}

1) JCS Joint Working Group. Guidelines for the diagnosis, treatment and prevention of pulmonary thromboembolism and deep vein thrombosis (JCS 2009). Circ J 2011; 75 : 1258-81.

2) Fedullo PF, Kerr KM, Auger WR et al. Chronic thromboembolic pulmonary hypertension. Semin Respir Crit Care Med $2000 ; 21: 563-74$.

3) JCS Joint Working Group. Guidelines for treatment of pulmonary hypertension (JCS2012). Available at: http:// www.j-circ.or.jp/guideline/pdf/JCS2012_nakanishi_h.pdf (Accessed on September 11, 2017)

4) Sakaragawa H, Tokuhiro K, Har M et al. Haikekkann naishikyou ni yori chinnkyusei kessennzou ga mitomerareta kyusei haikessenn sokusenshou no 2 shourei. Therapeut Res $2006 ; 27: 987-90$.

5) Ishida $K$, Ueda $H$, Kohno $H$ et al. Surgical treatment for acute pulmonary embolism. Jpn J Cardiovasc Surg 2015 ; 44 : 24955.

6) Hasegawa I, Boiselle PM, Hatabu $\mathrm{H}$ et al. Bronchial artery dilatation on MDCT scans of patients with acute pulmonary embolism : comparison with chronic or recurrent pulmonary embolism. AJR 2004 ; 182 : 67-72.

7) Doğan H, de Roos A, Geleijins J et al. The role of computed tomography in the diagnosis of acute and chronic pulmonary embolism. Diagn Interv Radiol 2015 ; 21 : 307-16.
8) Ng CS, Wells AU, Padley SP et al. A CT sign of chronic pulmonary arterial hypertension : the ratio of main pulmonary artery to aortic diameter. J Thorac Imaging $1999 ; 14$ : $270-8$.

9) Tanabe N, Sugiura T, Tatsumi K. Recent progress in the diagnosis and management of chronic thromboembolic pulmonary hypertension. Respir/Investig 2013 ; 51 : 134-46.

10) Azarian R, Wartski M, Collignon MA et al. Lung perfusion scans and hemodynamics in acute and chronic pulmonary embolism. J Nucl Med 1997 ; 38 : 980-3.

11) JCS Joint Working Group. Statement for balloon pulmonary angioplasty for chronic thromboembolic pulmonary hypertension (JCS 2014). Available at: http://www.j-circ.or.jp/ guideline/pdf/JCS2014_ito_d.pdf (Accessed on September 11, 2017)

12) Koie $S$, Matsuyama $H$, Nomura $M$ et al. Intravascular ultrasound and angioscopy. Nihon Rinsho 2003 ; 61 : 174450.

13) Committee for Scientific Affairs, The Japanese Association for Thoracic Surgery, Masuda M, Kuwano H et al. Thoracic and cardiovascular surgery in Japan during 2013: annual report by The Japanese Association for Thoracic Surgery. Gen Thorac Cardiovasc Surg 2015 ; 63 : 670-701.

14) Committee for Scientific Affairs, The Japanese Association for Thoracic Surgery. Masuda M, Okumura M et al. Thoracic and cardiovascular surgery in Japan during 2014 : annual report by The Japanese Association for Thoracic Surgery. Gen Thorac Cardiovasc Surg 2016 ; 64 : 665-97.

15) Gan HL, Zhang JQ, Sun JC et al. Preoperative transcatheter occlusion of bronchopulmonary collateral artery reduces reperfusion pulmonary edema and improves early hemodynamic function after pulmonary thromboendarterectomy. J Thorac Cardiovasc Surg $2014 ; 148$ : 3014-9. 